\begin{abstract}
Cameroon is covered by about 20 million hectares of forests. Timber exploitation is the second source of external income after petroleum. Besides, Cameroon's forest has several other functions. Yet the threat to the very existence and survival of this forest is rapidly increasing due to overexploitation by logging companies and for firewood. Despite its usefulness, a substantial volume of the wood felled by timber exploiters is abandoned as waste to rot. This waste can be used as firewood by households even for building and making of furniture by small-scale users like carpenters if they had access to it.

This paper encourages the use of timber waste as an alternative to kerosene, which has become very expensive and unaffordable due to the general rise in the price of petroleum products in recent years. The overexploitation of forests can therefore be limited by putting the waste timber into use. It will go along to reduce freshly cut wood which is usually cut illegally and uncontrollably and which is a major source of depletion of forest resources. This project, once achieved will forever last because it will always generate revenue to the groups involve in the collection and the distribution of forest waste which will make money from sales even if they were to sell cheaper since the major cost is transportation and the waste wood is also cheap to obtain from the logging companies or even costless since they have less interest in it.
\end{abstract}

\title{
ECONOMIC IMPACTS OF CLIMATE CHANGE: A MICRO-LEVEL EVIDENCE FROM NIGERIAN RICE AGRICULTURE
}

\author{
Joshua Ajetomobi ${ }^{l, *}$, Ajiboye Abiodun ${ }^{2}$ and Rashid Hassan ${ }^{3}$ \\ ${ }^{l}$ Department of Agricultural Economics, Ladoke Akintola University of Technology, Ogbomoso, Nigeria. \\ ${ }^{2}$ Department of Agricultural Economics, Ladoke Akintola University of Technology, Ogbomoso, Nigeria. ${ }^{3}$ Director \\ and Professor, Centre for Environmental Economics and Policy in Africa and Department of Economics, University \\ of Pretoria, Pretoria South Africa. Corresponding author: jsegun2002@yahoo.com
}

\begin{abstract}
This study employed the Ricardian approach to test the relative importance of climate normals (average longterm temperature and precipitation) in explaining the value of farm land used for rice production under irrigation and dry land conditions. A survey was done by interviewing 1200 rice farmers from 20 rice producing states in Nigeria. The states cover all the six geopolitical zones in the country. The results indicate that increase in temperature will reduce land rent per hectare for dry land rice farms while it increases the land rent for irrigated rice farms. Increase in precipitation on the other hand will cause a rise in land rent for both dry land and irrigated rice farms. The results clearly demonstrate irrigation as a significant techniques used by the farmers to adapt to the climate change.
\end{abstract}

JEL CODES: Q12, Q25

Keywords: Climate change, Irrigation, Land value, Rice, Nigeria.

\section{ВОЗМОЖНОСТИ ИСПОЛЬЗОВАНИЯ ЦИФРОВЫХ МОДЕЛЕЙ РЕЛЬЕФА В УПРАВЛЕНИИ ЗЕМЕЛЬНЫМИ РЕСУРСАМИ РЕГИОНА}

\author{
К. С. Тесленок, С. А. Тесленок \\ ФГБОУ ВПО «Мордовский государственный университет им. Н.П. Огарева», Географический \\ факультет \\ ул. Советская, 24, г. Саранск, Россия, 430011 \\ E-mail: kirilltesl@mail.ru,teslserg@mail.ru
}

\section{POSSIBILITY OF USING DIGITAL TERAIN MODELS FOR LAND MANAGEMENT IN THE REGION}

\author{
K. S. Teslenok, S. A. Teslenok \\ N. P. Ogarev Mordovian State University, Faculty of Geography \\ Sovetskaya St., 24, Saransk, Russia, 430011 \\ E-mail: kirilltesl@mail.ru,teslserg@mail.ru
}

